\title{
Evaluation of contact fungicide spray regimes for control of late blight (Phytophthora infestans) in southern Ethiopia using potato cultivars with different levels of host resistance
}

\author{
Shiferaw Mekonen ${ }^{1}$, Tameru Alemu ${ }^{2}$, Bekele Kassa ${ }^{3}$ \& Greg Forbes ${ }^{4}$ \\ ${ }^{1}$ Southern Agricultural Research Institute - SARI, Awassa Research Center, P.O. Box 06, Awassa, Ethiopia; ${ }^{2}$ Department \\ of Plant and Horticultural Sciences, Hawassa University, Awassa, P.O. Box 05, Awassa, Ethiopia; ${ }^{3}$ Ethiopian Agricultural \\ Research Organization, Holetta Agricultural Research Center, P.O. Box 2003, Addis Ababa, Ethiopia; ${ }^{4}$ Centro Internacional \\ de la Papa - CIP, Apartado 1558, Lima 12 Peru
}

Author for correspondence: Tameru Alemu, e-mail: tamerualemu@gmail.com

\begin{abstract}
Late blight is an important disease of potato in Ethiopia, causing up to $100 \%$ loss in susceptible cultivars. In this study, two putatively resistant cultivars of relatively recent introduction (Jalenie and Gudenie) and a widely grown susceptible cultivar (White Flower) were evaluated for late blight severity and yield under five different contact fungicide (mancozeb) regimes and in unsprayed plots. Trials were carried out at two major potato production locations in southern Ethiopia: Awassa and Kokate, located at 1700 and 2156 meters above sea level, respectively. Greater disease pressure occurred at Awassa but the three cultivars performed consistently based on relative disease severity levels at the two locations. While White Flower was assigned a susceptibility score of 8 (highly susceptible) in both sites, Jalenie had scores between 1 and 0, and Gudenie had scores of 3 and 4, in Awassa and Kokate, respectively. With Jalenie, one application of contact fungicide was sufficient in both trials, while for Gudenie, two sprays appeared more appropriate as little or no gain was clear with three or more sprays. With the susceptible White Flower, four sprays were beneficial but little benefit was evident with the fifth spray.
\end{abstract}

Key words: Oomycetes, plant disease control, reduced fungicide, resistant varieties, resource poor farmers

\section{INTRODUCTION}

In the context of soaring staple food prices which impact developing countries hardest, potato is an increasingly important alternative source of food and nutrition. This is especially true in Ethiopia, where the production area has increased dramatically over the last two decades (CIP, 2004). Late blight, caused by the oomycete Phytophthora infestans, is a devastating disease of potato worldwide (Hijmans et al., 2000). Yield losses due to the disease are attributed to both premature death of foliage and diseased tubers. In Ethiopia, the disease occurs throughout the major potato production areas and it is difficult to produce the crop during the main rainy season without chemical protection measures.

The National Potato Program within the Ethiopian Institute of Agricultural Research (EIAR), together with the International Potato Center (CIP) and several Ethiopian universities, has worked over the last two decades to introduce potato cultivars with resistance to $P$. infestans. Between 1987 and 2006, eighteen potato cultivars were released in Ethiopia (Woldegiorgis et al., 2008). All of these cultivars came from potato germplasm introduced by the CIP as varieties with resistance to $P$. infestans. Resistance in potato to $P$. infestans is notoriously unstable so the actual levels of resistance of the released cultivars are not known. The newer cultivars have slowly been replacing the conventionally grown cultivars, which are of unknown origin but presumably were introduced from Europe over the last century; all are susceptible to late blight. The degree of adoption of the cultivars released since 1987 is not known but adoption is slow due to lack of an extensive seed production system in the country.

To more effectively manage late blight, farmers have increasingly adopted fungicide application as a main control strategy. Nonetheless, losses due to the disease were estimated to be $6.5-70 \%$ and complete crop failures are frequently reported (Bekele \& Yaynu, 1996). Use of cultivars with different level of resistance can reduce the need for both fungicide application frequencies and doses (Shtienberg et al., 1994; Clayton \& Shattock, 1995; Grünwald et al., 2000; Kirk et al., 2001).

Management of potato late blight can be highly location specific and optimal use of new, resistant cultivars will probably require some degree of adaptive research (Kromann et al., 2009). Such research could be facilitated by information on the relative level of resistance of each candidate cultivar and the value of this resistance in reducing fungicide needs. Frequently this information is lacking and, until recently, there was no system for quantifying resistance in potato to $P$. infestans, which could be applied in Ethiopia 
or other tropical and sub-tropical locations (Yuen \& Forbes, 2009).

In addition to the benefits of reducing yield losses due to epidemics of late blight, planting resistant varieties can also contribute to reduce the health risks associated with fungicide applications. A number of studies have demonstrated the high human health risk associated with pesticide application in developing countries, where protective clothing is routinely not used (Yanggen et al., 2004). Reducing fungicide use by growing resistant potato cultivars could decrease this risk to human health, lead to less environmental contamination and increase the economic benefit for farmers. The objectives of this study were to determine the levels of resistance in two new cultivars being promoted in Ethiopia relative to a widely grown susceptible cultivar, and evaluate how effective this resistance is in the reduction of fungicide application frequency.

\section{MATERIAL AND METHODS}

\section{Description of the sites}

The research was conducted at Awassa and Kokate research centers of the Southern Agricultural Research Institute (SARI) of Ethiopia from end of June to November, 2008, which represents the main rainy season. The Awassa research farm center is located at $7^{\circ} 4^{\prime} \mathrm{N}$ and $38^{\circ} 31^{\prime} \mathrm{E}$ at a height of 1,700 meters above sea level (masl). During the experiment period, the center received an average annual rainfall of $750 \mathrm{~mm}$ with average monthly minimum and maximum temperatures of $12.8^{\circ} \mathrm{C}$ and $25.9^{\circ} \mathrm{C}$, respectively. On the other hand, the Kokate research center is in the Walayita zone, located at $6^{0} 52^{\prime} \mathrm{N}$ and $37^{\circ} 48^{\prime} \mathrm{E}$ at a height of 2156 masl. It had an average rainfall of $655 \mathrm{~mm}$ with average monthly minimum and maximum temperatures of $13.6^{\circ} \mathrm{C}$ and $24.2^{\circ} \mathrm{C}$, respectively. Awassa and Kokate have sandy loam and clay loam soil types, respectively. Both sites are suitable for potato production, and late blight pressure is generally high in both locations during the rainy season.

\section{Experimental design}

Three potato cultivars purportedly with different levels of resistance to late blight were used: Jalenie (CIP384321.19) and Gudenie (CIP-386423.13), which were obtained from the Holeta Agricultural Research Center, Western Ethiopia. Jalenie is known for its high level of resistance to late blight, whereas Gudenie is considered moderately resistant to the disease. Both have wide-range environmental adaptation in Ethiopia. Jalenie was released in 2002, while Gudenie was released in 2006 (Woldegiorgis et al., 2008). These were compared with a local cultivar referred to as White Flower, which is widely grown in the Shashemene, Awassa and Walayita areas of southern Ethiopia. White Flower is highly susceptible to late blight.

A randomized complete block design with a factorial model was applied with three replicates in each location, where one factor was cultivar and the other was fungicide treatment. Each potato cultivar was randomly combined with one of five frequencies of chemical spray (one, two, three, four and five applications) and a no-spray treatment, thus giving a total of 18 treatment combinations. Each plot was considered an experimental unit. Plots consisted of 4 rows with spacing of $0.3 \mathrm{~m}$ between plants and $0.75 \mathrm{~m}$ between rows, giving an overall dimension of $3 \mathrm{~m} \mathrm{X} 3 \mathrm{~m}$. To minimize fungicide drift between treatment combinations during spraying, plots were separated by two rows of maize. At planting, di-ammonium phosphate (DAP) and urea were side dressed at the rate of $195 \mathrm{~kg} / \mathrm{ha}$ and 165 $\mathrm{kg} /$ ha respectively. Mancozeb $80 \% \mathrm{WP}$, a contact fungicide, was applied as per the recommendation of the manufacturer (at a rate of $3 \mathrm{~kg} / \mathrm{ha}$ ) using a manually-pumped knapsack sprayer of 15 liter capacity. Spraying started at 45 and 50 days after emergence at Awassa and Kokate, respectively; spray initiation was based on the appearance of the first late blight symptoms. Subsequent applications were done for those treatments that required them at seven-day intervals for up to five consecutive weeks. Fungicide application dates were the $8^{\text {th }}, 15^{\text {th }}, 22^{\text {nd }}, 29^{\text {th }}$ of July and $5^{\text {th }}$ of August, 2008 in Awassa, and the $13^{\text {th }}, 20^{\text {th }}, 27^{\text {th }}$ of July, $3^{\text {rd }}$ and $10^{\text {th }}$ of August, 2008 in Kokate. Crop husbandry practices, such as cultivation and weeding, were carried out according to the farmers' practices in each location.

\section{Data collection and analysis}

\section{Disease development}

Disease onset (DO) in each cultivar was recorded in days after crop emergence. Starting with the appearance of the first late blight symptoms, each plant within each plot was visually evaluated for percent foliar infection at seven-day intervals. Evaluations continued until untreated plots of the susceptible variety no longer increased in disease severity. Percent disease severity values were averaged at the plot level and converted to the area under the disease progress curve (AUDPC) as described by Campbell and Madden (1990). Susceptibility to $P$. infestans was quantified in each cultivar using the interval scale of Yuen and Forbes (2009), which is derived from the AUDPC. For use of this scale, White Flower was assigned a susceptibility value of 8 .

\section{Yield and tuber blight}

Total tuber yield (TTY) of each experimental unit (plot) was determined by harvesting the two inner rows of each plot. Tubers were sorted as unmarketable (blighted, rotten and deformed) and marketable from the total tuber yields and the components were measured. All measures are given in $\mathrm{T} / \mathrm{ha}$, which was derived by extrapolation from the yield per plot. To determine the incidence of tubers with symptoms of tuber blight, five plants were randomly taken from each central row and tubers were cleaned and inspected superficially for symptoms of tuber blight. The percentage of infected tubers (TIP) averaged across the five plants was recorded for each plot.

Tropical Plant Pathology 36 (1) January - February 2011 


\section{Data analysis}

The AUDPC, DO, TIP and tuber yield (marketable and total yield) effects were assessed with analysis of variance (ANOVA). Preliminary analysis demonstrated that cultivar by treatment interactions was significant for all response variables and therefore ANOVAs were run separately for each cultivar by location combination. To determine which fungicide regimes were most appropriate, Fisher's protected least significant difference test at the 5\% significance level $\left(\mathrm{LSD}_{5 \%}\right)$ was used as a general threshold indicator of diminishing return on fungicide investment. A regime was considered appropriate when benefits of additional sprays could no longer be measured within this experimental setup. All analyses were done with the Statistical Analysis System (SAS version 91; SAS Institute, Cary, NC).

\section{RESULTS}

\section{Disease development}

Disease was more severe in Awassa, as was clear from the disease progress curves (Figure 1) and the AUDPC values of the unsprayed treatments (Table 1). Disease in the susceptible local cultivar reached slightly over $80 \%$ in Awassa, but only went to about $40 \%$ in Kokate. In both locations disease progress was atypical in that after reaching a high point at about 80 days after planting (dap), disease severity leveled off and eventually decreased. For this reason, only data evaluations up through 85 dap were used in the calculation of the AUDPC. At both locations DO was

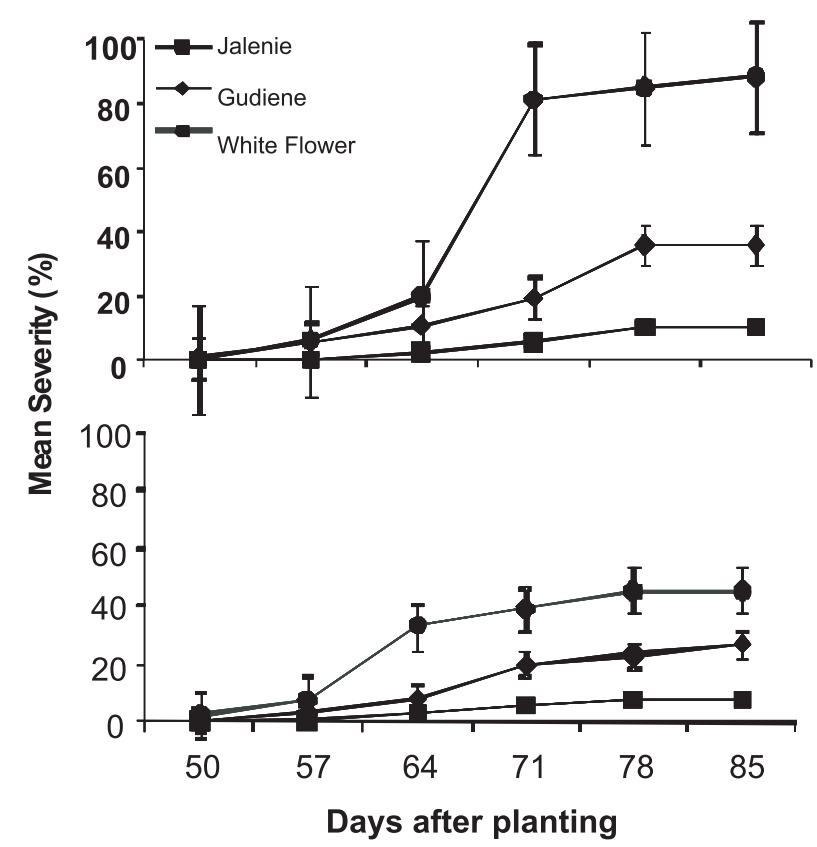

FIGURE 1 - A. Development of late blight on unsprayed treatments of three varieties of potato at Awassa and B. Kokate, southern Ethiopia, respectively. not affected by increasing fungicide use for any of the three cultivars; however, there was an apparent cultivar effect as DO occurred later in Jalenie and was always earliest in White Flower (Table 1). However, the experiment was not designed to statistically compare differences among cultivars. DO occurred sooner in Awassa for all cultivars.

\section{Cultivar resistance}

Cultivars clearly differed in their level of susceptibility to $P$. infestans, and the difference was generally consistent in the two locations. Whereas the local susceptible cultivar was assigned a susceptibility score of 8 , the most resistant cultivar, Jalenie, had a score of 1 (scores were rounded to nearest whole number) in Awassa and 0 in Kokate. Gudenie, was intermediate in both locations with a susceptibility score of 3 in Awassa and 4 in Kokate (Table 2). Resistance was also associated with TIP and was highest in the susceptible White Flower, followed by Gudenie. However, it is not known if TIP reflects levels of resistance, the effect of more foliage infection and therefore more inoculum, or both. Soil type can also play a role in tuber infection.

\section{Appropriate fungicide regimes}

Assessment of disease severity (AUDPC) and yield parameters (Table 1) for fungicide efficacy provided insight into the most appropriate fungicide application regimes. The susceptible local cultivar responded well to fungicide application and gave a positive AUDPC response to additional sprays up through the fourth spray in both locations (Table 1). The fifth spray continued reducing the AUDPC in both locations but the difference was not statistically significant in this test. Yield parameters provided a somewhat different view in that the fifth spray continued to give a significant increase in yield in Awassa, however not in Kokate. Thus, between four and five sprays were appropriate for White Flower for control of foliage blight in our tests.

The moderately resistant cultivar, Gudenie, also had a clear AUDPC response to additional fungicide sprays, although apparently for about three sprays. The LSD was difficult to use as a measure in Awassa because of overlapping groups but in both locations, there was only minimal reduction in the AUDPC after the third spray (Table 1). The pattern was similar for yield. At Awassa, there was no significant yield increase after two sprays, although there was a tendency for yields to increase with increasing sprays. The overall pattern was somewhat disrupted with Gudenie in Kokate, where marketable yields were increased with the fifth fungicide spray, although based on the AUDPC it is not clear that this was due to decreased late blight.

The highly resistant cultivar, Jalenie, also responded favorably for the AUDPC up to 2 sprays in Awassa, and 1 in Kokate, but it should be noted that the AUDPC was not high even without fungicide spray (Table 2 ). The very small amount of disease even without fungicide was consistent 
S. Mekonen et al.

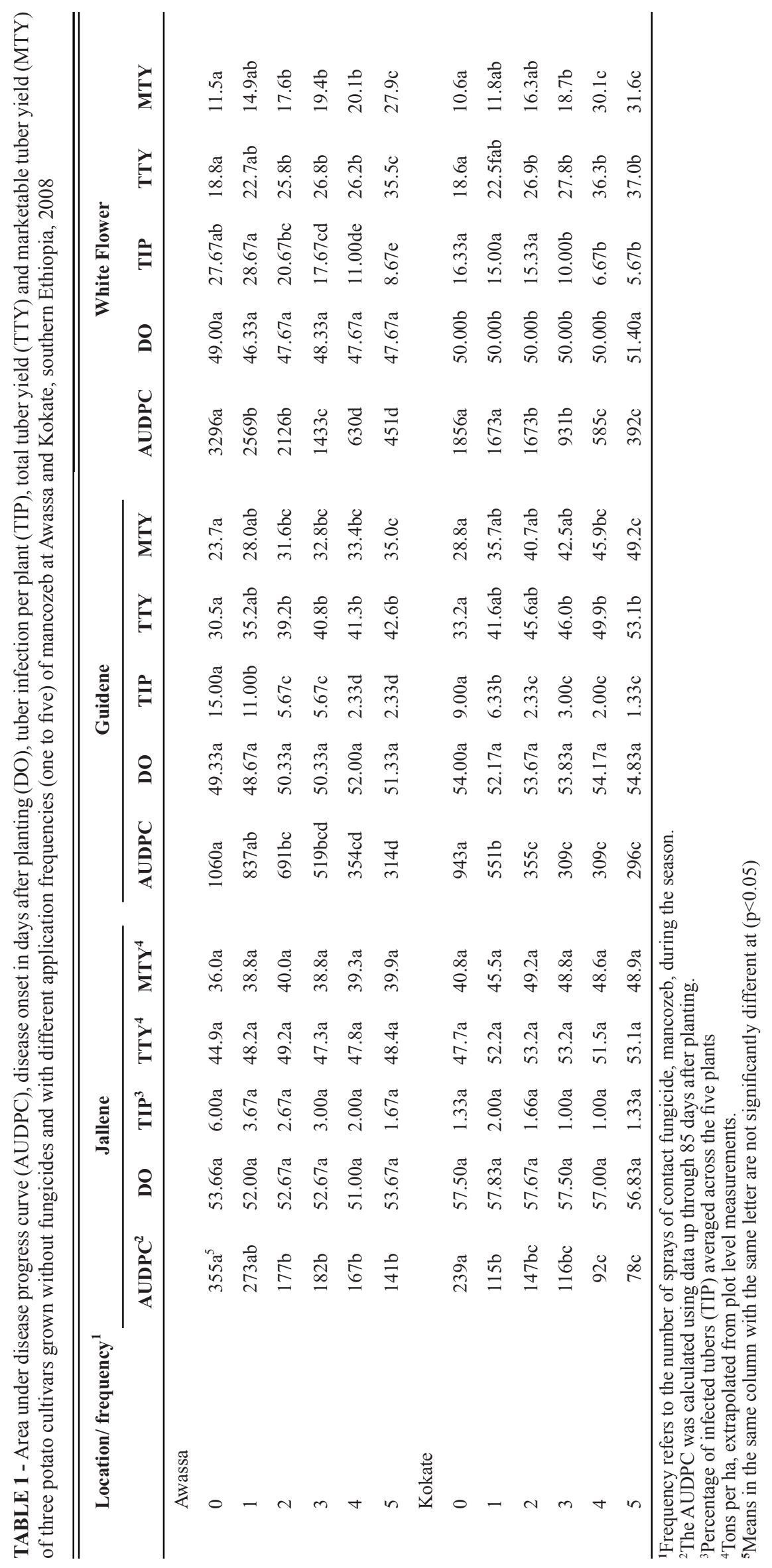


Evaluation of contact fungicide spray regimes for control of late blight...

TABLE 2 - Area under disease progress curve (AUDPC) and score values for susceptibility to Phytophthora infestans of three potato cultivars evaluated in Awassa and Kokate, Southern Ethiopia

\begin{tabular}{|c|c|c|c|c|c|c|}
\hline \multirow[t]{2}{*}{ Variable } & \multicolumn{3}{|c|}{ Awassa } & \multicolumn{3}{|c|}{ Kokate } \\
\hline & Jallene & Guidene & White Flower & Jallene & Guidene & White Flower \\
\hline AUDPC & 354 & 1060 & 3296 & 239 & 943 & 1856 \\
\hline Score ${ }^{\mathrm{a}}$ & 1 & 3 & 8 & 0 & 4 & 8 \\
\hline
\end{tabular}

${ }^{a}$ Score values based on AUDPC and calculated as described by Yuen and Forbes (2009); values are rounded to nearest whole number.

with yield parameters, where no fungicide effect could be measured in either location for Jalenie. The level of TIP was also affected by spray frequencies for Jalenie and White Flower. At Awassa, where the LB pressure was higher, the fourth and even fifth sprays appeared to provide benefit as there was a clear tendency for a continued reduction in TIP. In Kokate, where disease pressure was lower, the fifth, fourth and third were not significantly different in reducing TIP (Table 2).

\section{DISCUSSION}

This study demonstrated that three current Ethiopian potato varieties have different levels of susceptibility to $P$. infestans and that as a consequence, the effects of the most common contact fungicide, mancozeb, are cultivar dependent. The susceptibility of the three cultivars spanned the recently published scale of Yuen and Forbes (2009), from 0 (highly resistant) to 8 (highly susceptible) with one cultivar falling approximately in the middle. Although this scale is interval in nature (all units are equidistant) its relationship to fungicide requirements is not known. Increase in scale values should indicate a need for more fungicide, but the quantitative relationship between the two parameters has never been developed to our knowledge. Nonetheless, several researchers have demonstrated that susceptible cultivars require more fungicide than do resistant cultivars (Kato et al., 1997; Kirk et al., 2001; Namanda et al., 2004; Naerstad et al., 2007). In this investigation also, the susceptible cultivar responded well to the increased application of mancozeb up to the fourth spray at both locations. This represents two trials and is an indication that can be used for farmers and extension workers, but the finding is not necessarily a recipe for other situations. We particularly note that in neither location in our study did the unsprayed susceptible control reach $100 \%$ disease, probably due to a change in weather conditions during the season. Thus, under more continuously favorable disease conditions, five or even six sprays may be needed.

Management of the susceptible cultivar in our study differed somewhat from that of a recent study in Peru and Ecuador, where regular sprays (every 5 days and weekly) were not sufficient to control the disease. We do not know why the situations are different but potential factors include the base level of susceptibility of the cultivars (perhaps White Flower is not as susceptible as susceptible cultivars in Peru and Ecuador), the aggressiveness of the pathogen population; or differences in weather that may affect disease intensity, fungicide weathering or both. One study demonstrated with plant disease simulation that the pathogen population in Kenya and Uganda is probably less aggressive than that of the Andes (Forbes et al., 2009). However, the population in Kenya and Uganda is the "old" US-1 population, while that of Ethiopia appears to be different (Schiessendopplar \& Molnar, 2002). Different populations of $P$. infestans sometimes display different sensitivities to contact fungicides (Kato et al., 1997).

The moderately resistant cultivar, Gudenie, responded to reduction of AUDPC by additional fungicide sprays of two-three. Again, this probably represents a general guideline that may need modification for specific situations. Nonetheless, it is clear that by using Gudenie, farmers can reduce costs and risks of exposure to pesticides. This research also demonstrates that with the more resistant cultivars, there is probably no need to use more expensive systemic fungicides, some of which are prone to the development of insensitivity in the pathogen population (e.g., phenylamides). When using a contact fungicide, the safest way to exploit medium levels of resistance in foliage is probably to use a disease forecasting scheme to time the fungicide application and adjust the concentration according to the resistance of the cultivar (Naerstad et al., 2007). However, disease forecasting schemes for late blight have not been developed in most parts of sub-Saharan Africa.

Based on our results, the resistant cultivar Jalenie probably does not need fungicide applications in Ethiopia. This could be true, if the more severe disease in Awassa is representative of the areas where disease pressure is high in Ethiopia. Under more severe disease conditions, one or two sprays may be useful. It is also highly possible that the resistance in Jalenie is conferred by a major gene with a large effect. These have been notoriously shortlived in this pathosystem and fungicide protection could potentially prolong the functional life of the resistance gene by reducing the amount of inoculum reaching the plant and thereby reducing the pathogen population size. Use of a less hazardous and potentially less expensive fungicide, such as Bordeaux Mix or a phosphonate-based product may be an interesting option for Jalenie as long as resistance holds.

There was a strong cultivar effect for the amount of tuber blight (TIP) that could be related to cultivar resistance, the amount of disease in the foliage or both. Nevertheless, 
the levels found in all three cultivars, particularly in Jalenie and White Flower, were much higher than those reported for a study in Ecuador (Oyarzún et al., 2005). In that study, which involved extensive sampling in Ecuador, incidence was about $0.1 \%$. The only other tropical or subtropical study we know of was in Mexico (Torres \& Garcia, 1992), where tuber blight incidence was also rare. In contrast, in the United States (Dorrance \& Inglis, 1998) and Europe (Schepers \& van Soesbergen, 1995) tuber blight incidence can be high. Also, different factors, for example soil type, affect the field infection of potato tubers of different cultivars (Lapwood, 1977). However, the samples here were small and only from experimental plots; more extensive sampling should be done in Ethiopia to have a realistic idea of the tuber blight problem on a national level.

The resistance scale used here indicated that values for Jalenie and Gudenie were fairly consistent in the two locations but varied somewhat, primarily because the local cultivar appeared relatively more resistant in Kokate. This could indicate that when disease pressure is lower it is harder to distinguish among resistance levels and would therefore be a problem for evaluating across diverse environments. However, this problem does seem minor since scale values only varied by one unit. The discrepancy among locations could possibly also be linked to problems of identification of the control variety. The local varieties are known only by general phenotypes and it is not certain that both susceptible controls were the same genotype, even though they had the same name.

Reducing mancozeb application would contribute to improved health of farmers, as the fungicide is considered highly dangerous in low input agriculture (Wesseling et al., 2005). However, farmers often lack knowledge about the different level of resistance in cultivars and the advantages obtained by integration of host resistance with judicious use of fungicides. Thus, it is vital to help farmers develop such competence through training.

\section{ACKNOWLEDGEMENTS}

The research was supported by the Norwegian Cooperation and Development Agency (NORAD) to Hawassa University and Southern Agricultural Research Institute (SARI), Ehiopia.

\section{REFERENCES}

Bekele K, Yaynu H (1996) Tuber yield loss assessments of potato cultivars with different levels of resistance to late blight. In: Eshetu Bekele E, Abdulahi A, Yemane A (Eds.) Proceedings, $3^{\text {rd }}$ Annual Conference of Crop Protection Society of Ethiopia. 18-19 May, Addis Ababa. pp. 149-152.

Campbell CL, Madden LV (1990) Introduction to Plant Disease Epidemiology. New York NY. John Wiley and Sons.

CIP (2004) Ethiopia Late Blight Profile: Disease impact on industry, consumer and country http://research.cip.cgiar.org/ typo3/web/uploads/media/Ethiopia.pdf (April 20, 2010)

Clayton RC, Shattock RC (1995) Reduced fungicide inputs to control Phytophthora infestans in potato cultivars with high level of polygenic resistance. Potato Research 38:399-405.

Dorrance AE, Inglis DA (1998) Assessment of laboratory methods for evaluating potato tubers for resistant to late blight. Plant Disease 88:441-446.

Forbes GA, Landeo JA (2006) Late Blight. In: Gopal J, Khurana SM (Eds.) Handbook of Potato Production, Improvement, and Postharvest Management. Binghamton NY. Haworth Press Inc. pp. 279-314.

Forbes GA, Shtienberg D, Mizubuti E (2009) Plant disease epidemiology and disease management - has theory had an impact on practice? In: Integrated Pest Management: Innovation - Development Process. New York NY. Springer. pp. 351-368.

Grünwald NJ, Rubio-Covarrubias OA, Fry WE (2000) Potato late blight management in the Toluca Valley: forecasts and resistant cultivars. Plant Diseases 84:410-416.

Hijmans RJ, Forbes GA, Walker TS (2000) Estimating the global severity of late blight with GIS linked disease forecast models. Plant Pathology 49:697-705.

Kato M, Mizubuti ES, Goodwin SB, Fry WE (1997) Sensitivity to protectant fungicides and pathogenic fitness of clonal lineages of Phytophthora infestans in the United States. Phytopathology 87:973-978.

Kirk WW, Flecher DS, Douchs JM, Coombs Backer KM, Hammerschmidt R (2001) Effect of host plant resistance and reduced rates and frequency of fungicides application to control potato late blight. Plant Disease 85:1113-1118.

Kromann P, Taipe A, Perez WG, Forbes GA (2009) Rainfall thresholds as support for timing fungicide applications in the control of potato late blight in Ecuador and Peru. Plant Disease 93:142-148.

Lapwood DH (1977) Factors affecting the field infection of potato tubers of different cultivar by blight (Phytophthora infestans). Annals of Applied Biology 85:23-42.

Namanda S, Olanya OM, Adipala E, Hakiza JJ, El-Bedewy R, Baghsari AS, Ewell P (2004) Fungicide application and hostresistance for potato late blight management: benefits assessment from on-farm studies in S.W. Uganda. Crop Protection 23:10751083.

Naerstad R, Hermansen A, Bjor T (2007) Exploiting host resistance to reduce the use of fungicides to control late blight. Plant Pathology 56:156-166.

Njualem DK, Demo P, Mendoza HA, Koi JT, Nana SF (2001) Reaction of some potato genotypes to late blight in Cameroon. African Crop Science Journal 1:209-213.

Nyankanga RO,Wien HC, Olanya MO, Ojiambo PS (2007) Relationship between late blight (Phytophthora infestans) of potato on tuber and foliage as affected by disease severity on foliage, cultivar resistance and atmospheric and soil variables. Canadian Journal of Plant Pathology 29:372-387.

Oyarzún PJ, Garzon CD, Leon D, Andrade I, Forbes GA (2005) Incidence of potato tuber blight in Eucador. American Journal of Potato Research 82:117-122. 
Schepers HT, Van Soesbergen AM (1995) Factor affecting the occurrence and control of tuber blight. In: Dowley LA, Bannon E, Cooke LR, Keane T, O'Sullivan E (Eds.) Phytophthora infestans 150. Dublin, Ireland. Boole Press Ltd. pp. 171-176.

Schiessendoppler E, Molnar O (2002) Characterization of Phytophthora infestans population in Sub-Saharan Africa as a basis for simulation modeling and integrated disease management In: Late Blight: Managing the Global Threat. Proceedings, Global Initiative on Late Blight Conference, Hamburg, Germany. International Potato Center, Lima, Peru. p. 140 .

Shtienberg D, Raposo R, Bergerson SN, Legard DE, Dyer AT, Fry WE (1994) Inoculation of cultivar resistance reduced spray strategy to suppress early and late blight on potato. Plant Disease 78:23-26.

Torres JM, Garcia ER (1992) Supresividad del suelo al ataque de
Phytophthora infestans (Mont) de Bary en tubérculos de papa en Toluca, México. Fitopatologia (Peru) 27:61.

Wesseling C, Corriols M, Bravo V (2005)Acute pesticide poisoning and pesticide registration in Central America. Toxicology and Applied Pharmacology 207:S697-S705.

Woldegiorgis G, Gebre E, Lemaga B (2008) Potato Breeding. In: Woldegiorgis G, Gebre E, Lemaga B (Eds.) Root and Tuber Crops, the Untapped Resources. Addis Ababa. Ethiopian Institute of Agricultural Research. pp. 15-32.

Yanggen D, Donald CC, Charles C, Sherwood S (2004) Pesticide use in commercial potato production: Reflection on research and intervention efforts: Towards greater Ecosystem health in Northern Ecuador. Ecohealth 1:SU72-SU83.

Yuen JE, Forbes GA (2009) Estimating the level of susceptibility to Phytophthora infestans in potato genotypes. Phytopathology 99:783-786.

TPP 124 - Received 26 May 2010 - Accepted 15 November 2010 Section Editor: Eduardo S. G. Mizubuti 